研究

オボアルブミンとグルコース加らの加熱

フレーバーに対する共存比の影響

加藤保子* ・渡辺乾二**. 佐藤 泰**

Effects of Mixed Ratio of Ovalbumin and D-Glucose on Cooking Flavor

\author{
YASUKo Kato*, KenjI WATANABE** \\ and YASUSI SATO**
}

The mixed solution ( $\mathrm{pH} 10.0$ ) of ovalbumin and $\mathrm{D}$-glucose $(1: 3 \mathrm{w} / \mathrm{w})$ was heated at $120^{\circ} \mathrm{C}$ and the developed flavorous compounds were analyzed by gas-chromatography and by combined gas-chromatography-mass-spectrometry. Five compounds, 2methylpyrazine, furfural, 2-acetylfuran, 2-methylfurfural and furfurylalcohol, were identified.

The solution was heated at $70,100,120,150$ and $180^{\circ} \mathrm{C}$, respectively, and the solution of the two starting materials mixed with 1: 0.05, 1: 1.5 and $1: 3$ were heated at $120^{\circ} \mathrm{C}$.

The ratio of the five volatile compounds varied with changes of heating temperatures and mixed ratios.

(Received Apr. 8, 1974)

これまで加熱香気成分の研究材料としてとりあげられ たものは, ココフビーン゙1,21 コーヒー3!, ポプコーン4,

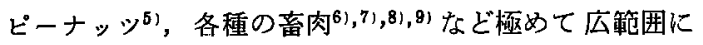
わたっており, 加熱温度, 加熱洔間などをファクターと して，香気成分の分別同定が行なわれている。これらの 香気成分の発生に関係ある前駆体として, 糖類, フミ， 酸類，脂質，多糖類，たん白質などがあげられモデル实 験によって香気成分の生成機構も考えられている。それ らのうちたえ白質と糖類の共存における加熱香気成分の 研究は比較的少なく, ラクトースとカゼインの乾燥混合 物の加熱によって生ずる褐変反応物中の揮発性化合物の 同定が FERRETTI ら 10111によって試みられている。この ような単一成分あるいは成分の混合によるモデル実験で は多くの場合その混合比を考えることなく行なわれてい る。

* 東海学園女子短期大学 (名古屋市昭和区天白町平針)

Women's College of Tokaigakuen. Tenpaku, Showa-ku, Nagoya.

** 名古屋大学農学部（名古屋市千種区不老町）

Faculty of Agriculture, Nagoya University. Huro, Tikusa-ku, Nagoya.
しかし調理における加熱香気はそれぞれの成分の混合 比をかえることによって，発生する場合が出てくる。そ の一例として, 沺白と各種浱度の焦糖の混合物の加熱肪 あげられる。また卵白では通常存在する遊離のグルコー スは $0.6 \%$ であり，乾燥卵白の製造では，このグルコー スと卵白蛋白質の加熱反応が問題になる。これらの問題 の基整として卵白蛋白質の主成分であるオボフルブミン とグルコースの混合物をそれぞれの割合を変えて加熱し た場合，発生する聥発成分定検討することは重要と考え られる。

そこでオボフルブミンとグルコースの混合物を加熱し て生成される揮発性化合物它分離同定し, さらに加熱温 度,オボフルブミンとグルコースとの混合㓶合による揮 発性化合物の生成割合の变化をも合わせて検討した。

\section{1. 実験材料およひ実験方法}

オボアルブミン（メルク社） $30 \mathrm{~g}$ とグルコース $90 \mathrm{~g}$ を $500 \mathrm{ml}$ の水に溶かし，水酸化ナトリウムで $\mathrm{pH} 10.0$ とする。温度調節器付なべに試料を入れ, $4^{\circ} \mathrm{C} / \mathrm{min}$ で昇 温し， 30 分後に $120^{\circ} \mathrm{C}$ とする。 $120^{\circ} \mathrm{C}$ になってから2 時間吸収し揮発性化合物をコールドトラップ（水，ドラ イアイス）にて捕集する。この操作を数回繰返し、コー ルドトラップ内に捕集された揮発性化合物をエーテル抽 出する。さらにそのェーテル溶液をアルカリ性水溶液で 振とうし，酸性部分を除去した。エーテル抽出物を無水 硫酸ナトリウムで脱水後, 濃縮してガスクロマトグラフ ィーおよびガスクロマトグラフィーーマススペクトロג トリーの試料とした。

(1) ガスクロマトグラフィーの条件

ガスクロマトグラフ装置法，日立 K 53 型検出器は水 素炎イオン検出器を用いた。10\% Carbowax $20 \mathrm{M}$ を Celite 515 にコーティングした 80〜100メッシュの充 填剤を $3 \mathrm{~mm} \times 2 \mathrm{~m}$ のカラムにつめて使用した。また分 析条件は， $\mathrm{H}_{2} ; 0.75 \mathrm{~kg} / \mathrm{cm}^{2}$, Air； $1.5 \mathrm{~kg} / \mathrm{cm}^{2}, \mathrm{~N}_{3}$; $0.85 \mathrm{~kg} / \mathrm{cm}^{2}$, Inj. Temp. $270^{\circ} \mathrm{C}$ で, $70^{\circ} \mathrm{C}$ から $230^{\circ} \mathrm{C}$ まで $2^{\circ} \mathrm{C} / \mathrm{min}$ の昇温で行なった。

(2) ガスクロマトグラフィーーマススペクトロメトリ - (以下 GC-MS との略す) の条件 
GC-MS 装置は，日立 RMU-6 E 型を使用した。充堤 戍として $10 \%$ PEG $20 \mathrm{M}$ を Celite $545 \mathrm{SK}$ にコーテ ィングしたものを用い, $70^{\circ} \mathrm{C}$ から $220^{\circ} \mathrm{C}$ まで $2^{\circ} \mathrm{C} / \mathrm{min}$ の昇温で行なった。またキャリフガスはーリウムを用い た。他の条件汢 WATANABE ら (1971) ${ }^{12)}$ の報告に示さ れた条件に準じた。

(3) 既知物質

標準試薬として2-メチルピラジン，フルフシール，2フセチルフラン, 2-メチルフルフラール, フルフリルフ ルコールを用い，これらの $10 \%$ Carbowax $20 \mathrm{M}$ によ る $70^{\circ} \mathrm{C}$ から $230^{\circ} \mathrm{C}$ ま $2^{\circ} \mathrm{C} / \mathrm{mim}$ で昇温した場合の 保持時間を求めた。

（4）加熱条件による揮発性化合物の生成割合の变化

オボフルプミン $30 \mathrm{~g}$ とグルコース $90 \mathrm{~g}(1: 3)$ を水 $500 \mathrm{ml}\left(\mathrm{pH} \mathrm{10.0)}\right.$ に溶かし, $70,100,120,150,180^{\circ} \mathrm{C}$ にてそれぞれ 2 時間加熱して掉発性化合物学捕集した。 酸性揮発性化合物を除去した後，それぞれのガスクロマ トグラムを求めた。ピーク面榼の総計から各揮発性化合 物のピーク面積の百分率を求め，揮発性化合物の生成割 合を比較検討した。

(5) オボフルプミンとグルコースの割合による揮発性 化合物の生成割合の変化

オボアルブミン $30 \mathrm{~g}:$ グルコース $1.5 \mathrm{~g}(1: 0.05)$, オ ボフルブミン $30 \mathrm{~g}:$ ダルコース $45 \mathrm{~g}$ (1: 1.5), オボフ ルブミン $30 \mathrm{~g}:$ グルコース $90 \mathrm{~g}$ (1:3) の割合でそれ ぞれ水 $500 \mathrm{ml}\left(\mathrm{pH} \mathrm{10.0)}\right.$ に溶かし, $120^{\circ} \mathrm{C}$ で 2 時間加 熱した。酸性揮発性化合物以外の揮発性化合物を抽出し た後, それぞれのガスクロマトグラム家求めた。各ピー ク面積百分率から揮発性化合物の生成割合を比較検討し t。

\section{2. 実験結果および考察}

オボアルブミン $30 \mathrm{~g}$ とグルコース $90 \mathrm{~g}$ を水 $500 \mathrm{ml}$ (pH 10.0) に溶かし， $120^{\circ} \mathrm{C} に 2$ 時間加熱した場合の 中性および塩基性揮発性化合物のガスクロマトグラムか ら主なピーク 5 つの保持時間および既知物質の保持時 間，さらに GC-MS の分析結果を Table 1 にまとめた。 すなおち、ピーク $1 ; 2-2$ チルピラジン，ピーク 2; フ

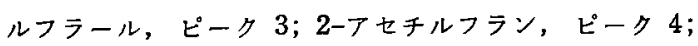
2-メチルフルフラール, ピーク 5; フルフリルアルコー ルと同定した。

オボフルブミン $30 \mathrm{~g}$ とグルコース $90 \mathrm{~g}$ を水 $500 \mathrm{ml}$

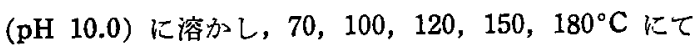
それぞれ 2 時間加熱した場合の 5 つの化合物の生成割合 を比較しだ結果を Table 2 に示す。低い温度で加熱した
Table 1. Volatile Compounds Identified in a Gulcose- Ovalbumin System

\begin{tabular}{lcrrrr}
\hline \hline $\begin{array}{l}\text { Peak } \\
\text { No. }\end{array}$ & Compound & \multicolumn{2}{c}{$\begin{array}{c}\text { Retention time } \\
\text { Sample }\end{array}$} & $\begin{array}{c}\text { Mass } \\
\text { Rpectral } \\
\text { peaks } \\
\mathbf{M}^{+} \text {m/e }\end{array}$ & $\begin{array}{c}\text { Mass } \\
\text { spectral } \\
\text { reference }\end{array}$ \\
\hline 1 & 2-Methylpyrazine & 8.4 & 8.4 & $94 / 67,39$ & a \\
2 & Furfural & 17.4 & 17.4 & $96 / 95,67,39$ & b \\
3 & 2-Acetylfuran & 19.7 & 19.5 & $110 / 95,39$ & c \\
4 & 2-Methylfurfural & 23.5 & 23.2 & $110 / 109,53$ & b \\
5 & Furfurylalcohol & 28.0 & 28.1 & $98 / 97,41$ & $\mathrm{c}$ \\
\hline
\end{tabular}

a: Bondarovich, et al. (1567), b: Heyns, et al. (1966), c: STOLL, et al. (1967).

Table 2. Proportion of Volatile Compounds Formed under the Various Heating Conditions

\begin{tabular}{lrrrrr}
\hline \hline $\begin{array}{l}\text { Peak } \\
\text { No. }\end{array}$ & $70^{\circ} \mathrm{C}$ & $100^{\circ} \mathrm{C}$ & $120^{\circ} \mathrm{C}$ & $150^{\circ} \mathrm{C}$ & $180^{\circ} \mathrm{C}$ \\
\hline 1. & 8.57 & 2.15 & 3.33 & 2.92 & 3.02 \\
2. & 4.51 & 24.02 & 26.27 & 18.83 & 35.65 \\
3. & 40.20 & 2.31 & 3.07 & 3.53 & 7.86 \\
4. & 0.00 & 3.29 & 2.02 & 2.36 & 13.33 \\
5. & 46.41 & 67.75 & 65.32 & 72.37 & 40.15 \\
\hline
\end{tabular}

Peak No. 1: 2-Methylpyrazine, 2: Furfural, 3: 2-Acetylfuran 4: 2-Methylfurfural, 5: Furfurylalcohol

場合には，2-フセチルフランおよびフルフリルフルコー ルがそれぞれ 40\% 以上また 2-メチルピラジンは 8.57 $\%$ 生成された。100,120,150 $\mathrm{C}$ で加熱した場合にはこ れら三つの場合ともほぼ同じ傾向を示し，フルフリルフ ルコール生成割合が $65 \%$ 以上に，またフルフラールも $16.8 \%$ から 26.3\% に増加した。さらに $70^{\circ} \mathrm{C} て ゙$ 加熱 した場合には生成されなかった 2ーメチルフルフラール が 2 3\% 生成された。逆に, $70^{\circ} \mathrm{C}$ 加熱時より2ーメチル ビラジンおよび 2-アセチルフランの生成割合は隇少し た。 $180^{\circ} \mathrm{C}$ で加熱すると， $150^{\circ} \mathrm{C} て ゙$ 加熱した場合に比べ てフルフラール，2-メチルフルフラール，2-フセチルフ ランの生成割合の増加抢よびフルフリルフルコール生成 割合の減少というようにさらに生成割合に变化が認めら れた。

オボフルブミンとグルコースの割合を 1:0.05, 1:1.5, $1: 3$ に変え $120^{\circ} \mathrm{C}$ で 2 時間加熱した場合の 5 つの揮 発性化合物の生成割合を Table 3 に示した。オボアル ブミンとグルコースの割合が $1: 0.05$ の時には 2-アセ チルフランの生成割合が $99 \%$ 以上を示し, その他の化 合物の生成は認めがたかった。グルコースの割合を 1 : 1.5 に增やすと, フルフリールアルコール生成割合が著 
Table 3. Proportions in the Formation of Volatile Compounds under the Various Ratio of Ovalbumin and Glucose

(\%)

\begin{tabular}{cccr}
\hline \multirow{2}{*}{ Peak No. } & \multicolumn{3}{c}{ Ovalbumin : Glucose } \\
\cline { 2 - 4 } & $1: 0.05$ & $1: 1.5$ & $1: 3$ \\
\hline 1 & 0.00 & 5.99 & 3.55 \\
2 & 0.00 & 9.93 & 28.13 \\
3 & 99.40 & 2.00 & 3.29 \\
4 & 0.00 & 0.90 & 3.13 \\
5 & 0.00 & 81.17 & 61.90 \\
\hline
\end{tabular}

Peak No. 1: 2-Methylpyrazine, 2: Furfural, 3: 2-Acetylfuran 4: 2-Methylfurfural, 5: Furfurylalcohol

しく増加し，80\% 以上を占めた。また 2-メチルピラジ ン,フルフラール，2-メチルフルフラールの生成がみら れるようになった。さらにグルコースを $1: 3$ に増やす と, フルフラール，2-メチルフルフラールの生成割合が 増加した。

HEYNS ら ${ }^{19)}$ はグルコースを $300^{\circ} \mathrm{C}$ で 3 時間, $500^{\circ} \mathrm{C}$ で 3 時間加熱して，また WALTER ら ${ }^{14)}$ は $250^{\circ} \mathrm{C} て ゙ 30$ 分加熱して，それぞれ加熱生成物を得ており，そのうち に2-アセチルフランを同定しているが，オボアルブミ ンとグルコースを加熱した時には，2-アセチルフラン は，70ㄷ で加熱した場合およびグルコースの割合が少 ない場合に多く生成された。この 2-フセチルフランは， コーヒー・やココアピーン ${ }^{(1) 2}$ からも揮発性化合物として 見いたされている。またフルフラールおよび 2-メチル フルフラールは, 加熱温度が高いほど, またグルコース の割合が多いほど多く生成された。QUA ら スを $250^{\circ} \mathrm{C}$ で 1 分間加熱した時にフルフラールを同定 しているが，糖の加熱生成物としてフラン系化合物は多 く報告されているものの, 概してフルフラール系列の化 合物の報告はまれである。また HEYNS ら ${ }^{18)}$ はDーグルコ ースからフルフリールナルコールは生じないと報告して いる。しかしオボフルブミンとグルコースとを加熱した 場合には，グルコースの割合が少ない時には生成されに くいが，加熱温度による影響は受けにくく，70 $\mathrm{C}$ で加 熱した場合でも多く生成された。

2ーメチルピラジンは，グルコースの割合が少ないと生 成されにくいが，70ㄷで加熱した場合にる生成された。 ピリジンおよびピラジン系化合物は，ピーナッッ゙， ポ

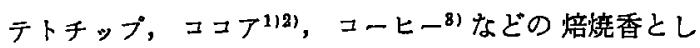
て，また牛肉をスキャキ風 ${ }^{12}$ に煮た時などに多くの報告

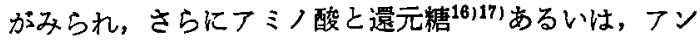

モニてと還元糖1)を加熱すると，メイラード反応によっ て多くのピラジンが生成されることが認められている。 またラクトースとカゼインを凍結乾燥後 $80^{\circ} \mathrm{C}$ に 8 日間 置いた時にもピリジン，ピラジンが分離同定されてい

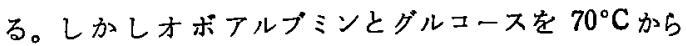
$180^{\circ} \mathrm{C}$ までの温度で 2 㭙間加熱した場合には，2-メチル ピラジン以外のピラジン系化合物を認めることはできな かった。

以上の結果のように，オボフルブミンとグルコースを 混合溶液として $70^{\circ} \mathrm{C}$ から $180^{\circ} \mathrm{C}$ の範囲で加熱すると, 2-アセチルフラン, フルフラールなどグルコースの加熱 分解生成物と考えられるるのと，蛋白質と糖質とのメイ ラード反応による生成物 2-メチルピラジンが同定され た。しかしこの実験条件のもとでは，限られた糖の熱分 解生成物およびピラジン系化合物の生成しか認められな 加った。

今後, これらの揮発性化合物をもとに, 卵白そのむの の加熱香気についても検討していくつもりである。

3. 要 約

(1) オボフルブミンとグルコース $(1: 3 \mathrm{~W} / \mathrm{W})$ の水 溶液（pH 10.0）を $120^{\circ} \mathrm{C}$ で 2 時間加熱した場合の揮 発性化合物を分離し，揮発性化合物として 2-メチルピ ラジン, フルフラール, 2-アセチルフラン, 2-メチルフ ルフラール,フルフリルアルコールを同定した。

(2) オボアルブミンとグルコース $(1: 3 \mathrm{~W} / \mathrm{W})$ の水 溶液（pH 10.0） 70,100, $120,150,180^{\circ} \mathrm{C}$ で加熱 した場合およびオボフルプミンとグルコースの割合を $1: 3,1: 1.5,1: 0.05$ と変化させ, それぞれ $120^{\circ} \mathrm{C}$ K $て 2$ 時間加熱した場合の上記の揮発性化合物の生成割合 を比較検討した。

(3) 2-メチルビラジンは，グルコースの割合が少ない と生成されにくいが，低温加熱 $\left(70^{\circ} \mathrm{C}\right)$ の場合にも生成 が認められた。

（4）2-アセチルフランは低温加熱およびグルコースの 割合が少ない場合に生成された。

(5) フルフラールおよび 2-メチルフルフラールは加 熱温度が高いほど，またグルコースの割合が多いほど多 く生成された。

(6) フルフリルフルコールはグルコースが多いほど多 く生成され，加熱温度の影響は受けにくく，70 $\mathrm{C}$ から 生成された。

最後に GC-MSの分析をしていたたいた長谷川香料株 式会社に深謝いたします。 


\section{文献}

1) van Praag M., Stein, H.S., Tibbetts, M.: J. Agr. Food Chem., 16, 1005 (1968).

2) Reineccius, G.A., KeEney, P. G., WeIsSBERger, W.: J. Agr. Food Chem., 20, 202 (1972).

3) Bondarovich, H. A., Friedel, P., Krampl, V., Renner, J.A., Shephard, F. W., Glanturco, M. A.: J. Agr. Food Chem., 15, 1093 (1967).

4) W alradt, J. P., Lindsay, R. C., Libbey, L. M.: J. Agr. Food Chem., 18, 926 (1970).

5) Mason, M.E., Johnsor, B.: J. Agr. Food Chem., 14, 454 (1966).

6) Hornstein, I., Crowe, P.F., Sulzbacher, W.L.: J. Agr. Food Chem., 8, 65 (1960).

7) Hornstein, I., CRowe, P.F.: J. Agr. Food Chem., 8, 494 (1960). :-

8) Hornstein, I., CRowe, P. F.: J. Agr. Food Chem., 11, 147 (1963).
9) Јасов, M. В.: Am. Perf., 70, 55 (1957).

10) Ferretti, A., Flanagan, V.P., Ruth, J. M.: J. Agr. Food Chem. 18, 13 (1970).

11) Ferretti, A., Flanagan, V.P.: J. Agr. Food Chem., 19, 245 (1971).

12) Watanabe, K., Sato, Y.: J. Agr. Food Chem., 19, 1017 (1971).

13) Heyns, K., Stute, R., Paulsen, H.: Carbohydrate Res., 2, 132 (1966).

14) Walter, R., Fagerson, I.S.: J. Food Sci., 33, 294 (1968).

15) QuA, A., FAGerson, I.S.: Institute of Food Technologists, Washington, D.C., May 24-28 (1964).

16) Koehler, P.E., Mason, M.E., Newell, J. A.: J. Agr. Food Chem., 17, 393 (1969).

17) Clark, A. V., Tannenbaum, S.R.: J. Agr. Food Chem., 18, 891 (1970).

（昭和 49 年 4 月 8 日受理）

\section{果糖の微生物に対する発育抑制効果}

$$
\begin{gathered}
\text { 手塚 堂*. 倉田 保*. 黒澤雄一郎* } \\
\text { 松本信二**. 小原哲二郎** }
\end{gathered}
$$

\section{The Growth Inhibitory Effect of Fructose on Microorganisms}

Tadashi Tezuka, Tamotsu Kurata, Yuichiro Kurosawa, Shinji Matsumoto and Tetsujiro Obara

The authors investigated the growth inhibitory effects of 9 kinds of sugars and sugar alcohols against fungi ( 7 strains), yeasts (2 strains) and bacteria ( 3 strains). The results obtained are as follows:

1) The growth of fungi and yeasts was inhibited by the solutions of fructose (50\%); glucose, sorbitol, xylitol $(50 \sim 60)$; and sucrose, maltitol $(60 \sim 70 \%)$.

2) The growth of bacteria was inhibited by the solutions of fructose (20\%); glucose, xylitol (20 $40 \%)$; and sucrose, maltose, sorbitol, maltitol (40 $60 \%$ ).

The growth inhibitory effects of sugars in combination with two commercial fungistatic agents (potassium sorbate and sodium propionate) were examined and they were remarkable especially in case of fructose.

(Received Aug. 1, 1974)

従来, 食品工業において, ショ糖, プドウ糖は欠くこ とのできない甘味料として，広く利用されてきてい るが，近年，低カロリー甘味料と称するマルチトール， キシリトール，ソルビトール，マンニトール，果糖など が登場し，急速に利用されつつある。筆者らは，この中 で，天然甘味料である果糖に注目した。

それは，従来その製造方法が困難なために，僅かに医 薬品，試薬などに利用されてきた程度であった果糖が， 最近技術の進歩により, 漸次大量生産が可能となり, 比 較的容易に入手できるようになったからである。

そこで，この果糖の食品への応用を目的とし，その基 礎的な検討として，9種類の糖及び糖てルコール（ショ 糖, 麦芽糖, 乳糖, ブドウ糖, 果糖, マルチトール, ソ ルビトール, マンニトール，キシリトール）について， 微生物に対する発育抑制作用を調べた。

その結果，果糖が他の糖類と比較して，すぐれた発育 抑制効果のあることを認めたので，それらの結果につい て報告する。

*帝国䂸器整薬株式会社 化学研究部(J崎市高津区下作延 1604)

Department of Chemistry, Research Laboratories, Teikoku Hormone Mfg. Co., Ltd. Kawasaki, Kanagawa.

** 東京農業大学農芸化学科（東京都世田谷区桜丘 1-1-1）

** Department of Agricultural Chemistry, Tokyo University of Agriculture, Setagaya-ku, Tokyo. 